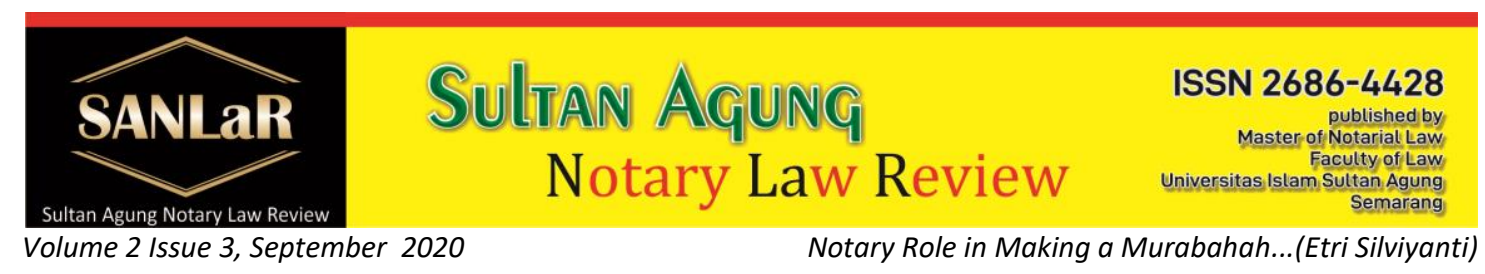

\title{
Notary Role in Making a Murabahah Account in Shari'a Banks
}

\author{
Etri Silviyanti ${ }^{*}$ and Gunarto ${ }^{* *}$ \\ *) Students of Master of Notary Law, Universitas Islam Sultan Agung (UNISSULA) \\ Semarang, E-mail: etrisilviya@gmail.com \\ ${ }^{* *}$ Lecturer of Master of Notary Law, Universitas Islam Sultan Agung (UNISSULA) \\ Semarang
}

\begin{abstract}
This study aims to determine and analyze the terms of the Murabahah financing agreement according to Islamic law and the role of the notary in making Murabahah financing agreement in Islamic banks. The type of research used is descriptive analytical which aims to parse the facts to obtain an overview, about the existing problems, examine and study legal facts. The results of the study concluded that under the terms of the Murabahah financing agreement on a Shari'a bank according to Islamic law must meet the pillars and conditions as described in Compilation of Shari'a Economic Law and the role of a notary in making Murabahah agreement deeds in Islamic banks, it is needed as a party of legality (legal force) and in making Murabahah deeds in Islamic banks that are notarized the formulation must be in accordance with Article 38 of the Law on the Position of Notary without leaving Shari'a principles as well as the mechanism/procedure for making notarial deeds.
\end{abstract}

Keywords: Notary Role; Murabahah Deed; Islamic Bank.

\section{Introduction}

Currently Islamic banking is quite in demand by the public, this is shown by the continued emergence and development of banks with Shari'a principles, one of which is the prohibition of usury. In conducting business activities of a Shari'a bank, apart from being regulated in the applicable laws, it must also comply with the Shari'a principles stipulated in the Al-Qur'an and hadith so that the implementation of the Shari'a Bank business activities constitutes the implementation and principles of Islamic economics which have the characteristics namely the prohibition of usury. ${ }^{1}$ Conventional banking recognizes the term interest, while Islamic banking does not recognize interest, but profit sharing (margin). This profit sharing principle is highly recommended. This is because it prioritizes stability. ${ }^{2}$

The enactment of Act No. 21 of 2008 makes Shari'a banking have a clear legal basis in terms of its institutional and operational systems. With the presence of this law, it provides greater opportunities for the public to obtain full banking services in accordance with Islamic law. One of which is that Islamic banking offers transactions

\footnotetext{
${ }^{1}$ Muhammad, Yusuf. (2011). Bisnis Syariah. Jakarta: Mitra Wacana Media. p.36

${ }^{2}$ Sumar'in. (2012). Konsep Kelembagaan Bank Syariah. Yogyakarta: Graha Ilmu. p.63
} 
that are not based on the concept of interest, it can be expected to more optimally serve people who have not can be touched by conventional banking, and provide financing in developing businesses based on the Islamic Shari'a system. ${ }^{3}$

Notary is a public official whose sole authority is to make authentic deeds regarding all agreements and decisions required by general regulations or by interested parties to be stated in an authentic deed, guarantees certainty of the date, keeps the deed and provides grosse, copy and excerpt. , all as long as the deed by a general rule is not assigned or excluded to other officials or persons. ${ }^{4}$

The position of a notary as a public official as intended by the provisions of the Law on Notary Position (UUJN) Number 30 of 2004 is an honorable position given by the state symbolically, which is in accordance with the provisions of Article 2 of the UUJN, namely a notary is appointed and dismissed by the Minister. The state minister in question is, the Minister of Justice (now called Menkumham), so a notary can carry out his duties freely without being influenced by the executive body or elements from several government agencies. The intention of freedom as intended is that the notary profession will not be afraid to carry out its position, so that it can act neutral and independent. ${ }^{5}$

A Notary Deed is needed because there are two reasons, namely being ruled by law and for the sake of proof. For the first reason, the law orders that an act that is carried out by setting out a notary deed is an obligation. Then the second reason is for the sake of proof, this is because an event which is stated in a deed is used to prove past events. If the deed is in the form of a notary deed, it will be more trustworthy because it has perfect evidentiary power because its truth is trustworthy and does not require other evidence. ${ }^{6}$

What is meant by Shari'a principles in the UUPS is the principle of Islamic law in banking activities based on fatwas issued by institutions that have the authority to determine fatwas in the field of Shari'a. Shari'a or Shari'a, literally, is the water source path, namely it must be followed by every Muslim. Shari'a contains the law of Allah and the provisions of His Messenger which are prohibitions and orders in all aspects of human life. ${ }^{7}$

By implementing the role of the notary profession who is fair, honest, transparent and neutral (not taking sides) in managing public funds in the making of agreements and guarantee letters of guarantee rights in financing contracts at a Shari'a Bank, there will be customer or public trust in a Shari'a Bank. Customers will feel served and treated ethically so that it will bring out customer satisfaction. If the customer is satisfied with the services provided by a Shari'a bank, the customer will be loyal in using the services of a Shari'a bank.

By applying honesty in running a business will increase the value of the business itself. The increasingly fierce level of competition coupled with increasingly critical

\footnotetext{
${ }^{3}$ Agusmantoro. (2009). Perbankan Syari'ah. Jakarta: LPFE Usakti. p.477

${ }^{4}$ S, Laurensius Arliman. (2015). Notaris dan Penegak Hukum Oleh Hakim. Yogyakarta: Deepublish. p.2

${ }^{5}$ Waluyo, Dedy Rajasa. There is Only One General Officer, namely a Notary Public. Notary Journal AprilJune 2013. Ed. p.41

${ }^{6}$ Supramono, Gatot. (2009). Perbankan dan Masalah Kredit Suatu Tinjauan di Bidang Yuridis. Jakarta: Rineka Cipta. p.137

${ }^{7}$ Article 1 number 7 Act No. 21 of 2008 concerning Islamic Banking.
} 
consumers requires businesses to maintain customer satisfaction. If customer satisfaction is maintained, the company will be sustainable and reliable in the long term. On the other hand, if honesty behavior is neglected, it can make the company lose the trust of the community and even possibly be prosecuted before the law. Management that does not apply the values of honesty behavior and is only oriented towards short-term profit (goals) will not be able to survive in the long term. ${ }^{8}$

Therefore the role of a notary is in the principles of honesty, fairness and an attitude of transparency and neutrality (not taking sides with anyone) in a the agreement deed at the Shari'a Bank needs to be applied and based on this background, the authors are interested in researching and discussing the role of the Notary in making Murabahah agreement deeds at Islamic Banks.

The objectives to be achieved by the authors in this study are: To know the terms of the Murabahah Financing Agreement in Islamic Banks according to Islamic Law; dab to find out the Role of Notaries in Making Murabahah Financing Deeds in Shari'a Banks in Accordance with Act No. 2 of 2014 concerning Notary Position.

\section{Research Methods}

The approach method used is Normative juridical approach. With analytical descriptive research specification. This research uses primary and secondary data types. Primary data, obtained from the field, data obtained from respondents. Data collection methods will be done through: Library Studies and Field Studies. Data obtained from document studies and field studies after they are complete and have been checked for validity will be analyzed qualitatively, then compiled systematically in order to obtain clarity on the problem then deductive conclusions are drawn, namely from general things to specific things.

\section{Results and Discussion}

Notary is a public official who has the authority to make authentic deeds to the extent that the making of certain authentic deeds is not specific to other public officials. ${ }^{9}$ The making of authentic deeds is required by laws and regulations in order to create legal certainty, order and protection. In addition, authentic deeds made by or in front of a notary, not only because they are required by laws and regulations, but also because interested parties want them to ensure the rights and obligations of the parties for certainty, order and legal protection for the parties concerned at the same time for society as a whole.

Notaries make authentic deeds which are the strongest and most fulfilling means of proof that have an important role in every legal relationship in every community life. In various business relationships, banking, social activities, and others, the need for written evidence in the form of authentic deeds is increasing in line with the growing

\footnotetext{
${ }^{8}$ Aziz, Abdul. (2013). Etika Bisnis Perspektif Islam. Bandung: Alfabeta. p.66

${ }^{9}$ Notodisoerjo, R. Soegondo. (1993). Hukum Notariat di Indonesia (Suatu Penjelasan). Jakarta: PT. Raja Grafindo Persada. p.12
} 
demands for legal certainty in various economic and social activities, both at the national and international levels. The existence of an authentic deed can provide legal certainty for the holder, and prevent disputes in the future, and even if a dispute cannot be avoided, the authentic deed is the strongest and most fulfilling written evidence in the dispute resolution process.

Increased legal knowledge and awareness of the community today has also had a major impact on various business agreements in the field of Islamic banking. The public understands that a notary is an important element in every banking transaction operation, especially in terms of making credit/financing guarantee deeds, debt acknowledgment, grosse deed, legalization and waarmerking, and other regulated notary duties. by laws and regulations. In addition, notaries are also given the authority to provide legal advice to their clients in order to achieve high legal awareness, namely to realize and live up to their rights and obligations so that the transactions agreed upon before a notary are legally defective. ${ }^{10}$

Meanwhile, the source of law in the perspective of the Al Qur'an regarding verses related to notaries is mentioned in many chapters, both implicitly and explicitly. Several verses that collaborate on notarization, including QS Al Qalam, QS Al Alaq paragraph 4, and QS Al Baqarah verse 282. In this verse Allah commands that in debt transactions, accounts and receivables must be recorded, where the duties and authority of recording must be professional and correct in accordance with the demands Ilahi. Islamic business transactions, the embryo of trust begins with the execution of transactions (akad/aqd) in accordance with the Al Qur'an and al-Hadith, all the implementation of these transactions aims to eliminate the number of fraud, disputes, or all kinds of negative impacts arising from a transaction The contract is one of the origins of a business transaction. ${ }^{11}$ To be able to understand the concept of Islamic finance, extensive knowledge is needed so that they can understand well the concept of Shari'a and finance in a balanced manner. Each component in the banking system needs to have a correct understanding of the concept of Islamic finance.

Notary, apart from having the authority to make authentic deeds both by him and in front of him, which is a notary's main daily duties, can also take the following actions:

a. Acting as a legal advisor, especially concerning civil law issues in a broad sense (privaat);

b. Registering (waarmerking) on deeds or under-handed documents and documents (stukken);

c. Legalize signatures;

d. Creating and ratifying (waarmerking) copies or derivatives of various documents (copy collationee);

e. Strive to separate entities such as Limited Liability Companies/Foundations in order to obtain approval/ratification as legal entities from the Minister of Law and Human Rights.

In formal juridical terms, the existence of a Shari'a bank has been recognized in the laws and regulations in Indonesia, including the existence of a Shari'a Rural Bank. With

\footnotetext{
${ }^{10}$ Adil. (2011). Mengenal Notaris Syariah. Bandung: Citra Aditya Bakti. p.85-86

${ }^{11}$ Fauzia, Ika Yunia. (2013). Etika Bisnis Dalam Islam. Jakarta: Kencana. p.15
} 
the issuance of Act No. 21 of 2008 concerning Shari'a Banking, which states that a Shari'a Bank is a Bank that carries out its business activities based on Shari'a Principles and by type consists of Shari'a Commercial Banks and Shari'a Rural Banks.

Islamic banks as financial institutions utilize notary legal services in every business agreement, such as fiduciary security and mortgages. In general, conventional banks are more likely to involve notaries in making agreement/engagement deeds compared to Islamic banks. However, currently Islamic banks as a sub-system of the national banking system which are specifically regulated in Act No. 21 of 2008 concerning Islamic Banking (UUPS) also use notary legal services in their business activities, especially those related to the Deed of Financing. (AAP). However, what needs to be emphasized here are the products of Islamic banks that use the principles and principles of Islamic economic law. ${ }^{12} \mathrm{In}$ order for an agreement to be legally enforceable, it must be recorded before a notary. Therefore, every Shari'a business, always requires a notary as an official who makes an authentic deed in accordance with his duties as regulated in Law of the Republic of Indonesia Number 2 of 2014 concerning the position of a notary.

In the perspective of Shari'a economic law, there are at least three theories that can be used to examine the role of notaries in the practice of business agreements in Islamic banking. ${ }^{13}$ The theoretical foundations in question include iltizam theory, agreement theory and legal criticism theory. The three of them can be reduced through a legal philosophy approach from the universal principles of Shari'a economic law found in the Al Qur'an, al-Sunnah, and ijtihad. ${ }^{14}$

Cooperation between a notary and a Shari'a bank in making a deed of financing with Shari'a principles, in principle the contract that is usually handled by notaries consists of:

a. Musyarakah financing, namely financing between 2 (two) parties to conduct a certain business and from that business the profits will be shared according to the agreement.

b. Mudharabah financing, which is financing in which one party is the manager while the other party is the provider of capital. Meanwhile, the principal repayments are adjusted to the cash flow of the customer so that it will not burden the customer.

c. Financing on the principle of ijarah or lease.

d. Murabaha Financing.

In this assignment, lies the giving of a sign of trust to these officials and the granting of evidentiary power to the deeds they make which legally have three powers of proof, namely the Strength of Physical/External Evidence, the Power of Formal Evidence, and the Power of Material Evidence.

\footnotetext{
${ }^{12}$ Anshori, Abdul Ghofur. (2008). Aspek Hukum Reksadana Syariah Di Indonesia. Bandung: Refika Aditama. p.61-62

${ }^{13}$ Anwar, Syamsul. (2007). Hukum Perjanjian Syariah Studi tentang Teori Akad dalam Fikih Muamalat. Jakarta: Raja Grafindo Persada. p.43

${ }^{14}$ Hasin, M. Ali. (2003). Berbagai Macam Transaksi dalam Islam: Fiqh Muamalat. Jakarta: PT Raja Grafindo Persada. p.44
} 
Therefore, based on the results of an interview with a notary in Kendari City, the role of the notary in making a financing agreement deed in a Shari'a bank is that in terms of financing, it always requires an agreement that contains a complete clause to ensure legal certainty in order to minimize the risk by the Islamic bank and also still be guided by Shari'a economic law so that the deeds made are harmonious and the requirements are in accordance with Shari'a principles. ${ }^{15}$

Based on the results of research at PT. Bank BRI Syari'ah KC Kendari has guidelines for making Murabahah agreement deeds using notarial deeds and underhand deeds. With a limit on the number of financing ceilings given to be made with a notary Murabahah financing deed. In formal juridical terms there are 2 (two) types of contracts made by Islamic banks, namely: ${ }^{16}$

a. Murabahah agreement under hand or deed under hand;

b. Murabahah agreement made by and before a notary (notary) or an authentic deed.

Notary Position in Making Murabahah Agreement Deed at PT. Bank BRI Syari'ah Tbk KC Kendari is based on a Decree of the Directors of PT. Bank BRI Syari'ah Tbk. And for financing in the Shari'a Bank there are conditions that are situational in nature, namely if the proposed financing ceiling is not too large, the Murabahah financing agreement is carried out under hand only. In this case the Bank has made a standard or standard agreement, the signing of which is carried out before the disbursement process of the financing.

In formulating the Murabahah agreement deed, a notary must pay attention to and apply the matters stipulated in the Law on Notary Position, as well as the importance of understanding in the field of Islamic banking. ${ }^{17}$ Deed a notarized financing agreement, in order to be referred to as an authentic deed, must comply with the provisions of Article 1868 of the Civil Code, which contains the following contents:

"An authentic deed is a deed made in the form prescribed by law by or before a public official who has the authority to do so at the place where the deed was drawn up".

A notarial deed of financing in a Shari'a bank must follow the form prescribed by the Law, in this case Article 38 of Act No. 2 of 2014 concerning Amendments to Act No. 30 of 2004 concerning Notary Position which regulates the form of a notary deed. The Law on Notary Position is general in nature, not only as a guideline for deeds in general, but also as a guideline for deeds in the field of Islamic Banking, considering that the regulations regarding deeds in the field of Islamic banking have not been specifically regulated.

So that in making a financing contract at a Shari'a bank it does not violate the provisions of Article 38 UUJN by adding the sentence Bismillah at the beginning of the deed and has the risk of the deed being degraded into an inauthentic deed and having the power of proof such as deed under hand, the sentence Bismillahirrahmaanirrahiim can be placed in the contents of the deed. The contents of the deed contain the wishes

\footnotetext{
${ }^{15}$ Interview with Hidayat, SH, Notary in Kendari City on January 12, 2020 at 11.30 WITA

${ }^{16}$ Research Results at PT. Bank BRIsyariah KC Kendari, on January 10, 2020 at 12.30 WITA

${ }^{17}$ Darus, M. Luthfan. (2017). Hukum Notariat dan Tanggungjawab Jabatan Notaris. Yogyakarta: UII Press. p.17-20
} 
and desires of the interested parties, especially those within the scope of Islamic banking. ${ }^{18}$

A notary public has responsibility for the deed of the Murabahah financing agreement made in front of him authentically. Regarding the deed, the notary has full responsibility regarding the correctness and accuracy of the contract construction so that the subjective and objective conditions of the contract are fulfilled, so that the deed made before a notary public, it is true and authentic which is very basic to be a deed of agreement which has the strength of perfect evidentiary value. Notary in formulating the deed of the deed at the request of the parties based on the procedure or mechanism/procedure of making the deed of notary. So that the Notary in carrying out his/her duties follows the applicable legal provisions, in Shari'a banking business practice there are no specific regulations regarding Shari'a financing contracts including limiting provisions regarding financing clauses, therefore notaries are not required to add or change their own terms and habits that have been practiced so far. Until now, notaries comply with the provisions of the Law on the Position of Notary Public and general provisions regarding Islamic banking. ${ }^{19}$

The role of a notary in the implementation of Islamic banking as legality (legal force), which makes the notary financing agreement and the collateral agreement deed. In addition, in service functions, notaries who have an attitude of honesty, fairness, transparency and neutrality (not taking sides) in making Murabahah financing agreement is an added value for the public to be able to trust Shari'a financial institutions as a place for Murabahah financing contracts that use collateral/guarantees as a condition for the financing contract. Customer satisfaction and trust are very valuable things in order to maintain the company's existence in the future. With services in the form of mutual trust, having an attitude of honesty and fairness that is contained in a notary public and given to customers will spur trust that leads to satisfaction or failure of a customer. In this case customer satisfaction is the level of a person's feelings after comparing the performance (results) that are felt compared to expectations. At PT. Bank BRI Syari'ah Tbk KC Kendari, a contract that uses the services of a notary, one of which is the Murabahah contract, in the sense that Murabahah is a sale and purchase agreement between a Shari'a Financial Institution and a Customer, where the Shari'a Financial Institution provides the goods needed by the customer then sells it to the customer concerned for the cost plus a fee/ujroh agreed between the Shari'a Financial Institution and the customer. ${ }^{20}$

\section{Closing}

The role of a notary in making Murabahah agreement deeds at Islamic banks is needed as a party of legality (legal force). Notaries who have an attitude of honesty, fairness, transparency and neutrality (not taking sides with anyone) is an added value for the

\footnotetext{
${ }^{18}$ Nurwulan, Pandam. (20019). "Sharia Banking Agreement and Its Application in the Notary Deed According to the Law on Notary Position". Volume 25.

${ }^{19}$ Faqih, Aunur Rohim. (2017). Bank Syariah, Kontrak Bisnis Syariah \& Penyelesaian Sengketa di Pengadilan. Yogyakarta: FH UII Press. p.205-206

${ }^{20}$ Research Results at PT. Bank BRIsyariah KC Kendari, on January 10, 2020 at 12.30 WITA
} 
public to be able to trust Islamic financial institutions as a place for Murabahah financing contracts to occur. In addition, in order for an agreement to be legally enforceable, it must be recorded where the duties and authority of registration must be professional and correct in accordance with divine demands. This is contained in the Al Qur'an and al-Hadith which instructs that debt and credit transactions must be recorded. In formulating Shari'a deeds, a notary must pay attention to and refer to the form of deed stipulated in the Law on Notary Position. A notary who handles Shari'a deeds should be a Muslim who really understands the principles of Shari'a. It is necessary to have a separate independent supervisory agency apart from DSN and Bank Indonesia, which really supervises and ensures that each financing agreement fully complies with the provisions of Islamic law and the provisions in positive law.

\section{References}

Journals:

[1] Nurwulan, Pandam. (20019). "Shari'a Banking Agreement and Its Application in the Notary Deed According to the Law on Notary Position". Volume 25.

[2] S, Laurensius Arliman. (2015). Notaris dan Penegak Hukum Oleh Hakim. Yogyakarta: Deepublish.

[3] Waluyo, Dedy Rajasa. There is Only One General Officer, namely a Notary Public. Notary Journal ed. April-June 2013.

Books:

[1] Agusmantoro. (2009). Perbankan Syari'ah. Jakarta: LPFE Usakti.

[2] Anshori, Abdul Ghofur. (2008). Aspek Hukum Reksadana Syari'ah Di Indonesia. Bandung: Refika Aditama.

[3] Anwar, Syamsul. (2007). Hukum Perjanjian Syari'ah Studi tentang Teori Akad dalam Fikih Muamalat. Jakarta: Raja Grafindo Persada.

[4] Adil. (2011). Mengenal Notaris Syari'ah. Bandung: Citra Aditya Bakti.

[5] Aziz, Abdul. (2013). Etika Bisnis Perspektif Islam. Bandung: Alfabeta.

[6] Darus, M. Luthfan. (2017). Hukum Notariat dan Tanggungjawab Jabatan Notaris. Yogyakarta: UII Press.

[7] Faqih, Aunur Rohim. (2017). Bank Syari'ah, Kontrak Bisnis Shari'a \& Penyelesaian Sengketa di Pengadilan. Yogyakarta: FH UII Press.

[8] Fauzia, Ika Yunia. (2013). Etika Bisnis Dalam Islam. Jakarta: Kencana.

[9] Hasin, M. Ali. (2003). Berbagai Macam Transaksi dalam Islam: Fiqh Muamalat. Jakarta: PT Raja Grafindo Persada.

[10] Muhammad, Yusuf. (2011). Bisnis Syari'ah. Jakarta: Mitra Wacana Media.

[11] Notodisoerjo, R. Soegondo. (1993). Hukum Notariat di Indonesia (Suatu Penjelasan). Jakarta: PT. Raja Grafindo Persada.

[12] Sumar'in. (2012). Konsep Kelembagaan Bank Syari'ah. Yogyakarta: Graha Ilmu.

[13] Supramono, Gatot. (2009). Perbankan dan Masalah Kredit Suatu Tinjauan di Bidang Yuridis. Jakarta: Rineka Cipta. 
Regulation:

Article 1 number 7 Act No. 21 of 2008 concerning Islamic Banking.

Interviews:

[1] Interview with Hidayat, SH, Notary in Kendari City on January 12, 2020 at 11.30 WITA

[2] Interview at PT. Bank BRI Syari'ah KC Kendari, on January 10, 2020 at 12.30 WITA 